\title{
IMPROVED CONSTRUCTION OF CONCRETE VIADUCTS WITH MOVABLE SCAFFOLDING SYSTEM IN SPAIN
}

\author{
José Ramón Díaz de Terán ${ }^{1}$, Vladimir Guilherme Haach², Jose Turmo³ ${ }^{3}$ Juan José \\ Jorquera-Lucerga ${ }^{4}$. \\ ${ }^{1}$ Ph.D. Civil Engineer. Researcher. University of São Paulo (Av. Travalhador São-Carlense, 400-Centro, \\ São Carlos-SP, 13566-583, Brazil) E-mail: jringcamjunior@gmail.com \\ ${ }^{I}$ Ph.D. Civil Engineer. Professor. University of São Paulo (Av. Travalhador São-Carlense, 400-Centro, \\ São Carlos-SP, 13566-583, Brazil) E-mail:vvhaach@sc.usp.br. \\ ${ }^{3}$ Ph.D Civil Engineer, Professor, Universitat Politècnica de Catalunya (Construction Engineering \\ Department, B1, 110A, C. Jordi Girona, 1-3,08034 Barcelona, Spain).E-mail: jose.turmo@upc.edu \\ ${ }^{4}$ Ph.D. Civil Engineer. Assistant Professor. Polytechnic University of Cartagena. (Paseo Alfonso XIII, 52 \\ 30203 - Cartagena, Spain) E-mail: juanjo.jorquera@upct.es
}

\section{ABSTRACT}

The current paper relates the state of art of the construction of viaducts with movable scaffolding system (MSS). Two different procedures are introduced: the traditional sequence and the new sequence applied to some viaducts in Spain. The traditional sequence consists in a first casting phase that is formed by the bottom flange and webs and a second casting phase that is formed by the top flange of the deck. Once the first and second casting phases are completed, the total prestressing force is introduced. The new sequence consists in a first casting phase of self-supporting core that is formed by the bottom flange, webs and only a portion of the top flange, and a second casting phase that is formed by the central zone of the top flange. As soon as the self-supporting core is completed, a partial prestressing force is introduced so that the scaffolding can advance to the next span. Both sequences are described with their constructive peculiarities and issues.

Keywords: Movable Scaffolding System, span by span casting, loop joint, critical path, transverse deformation, presstresing stage, traditional sequence, new sequence, self-supporting core.

\section{Introduction}


Bridge construction is a wide field of study in many aspects related to engineering (Voo et al, 2014), (Vicente et al, 2014), (Kim et al, 2014). In this sense, this paper introduces a new construction procedure for bridges with movable scaffolding system.

This new sequence is based on a self-supporting core that can be partially prestressed and allows the advance of the scaffolding to the next span. The main advantages of this new sequence is that it permits the second casting phase out of the critical path and clarifies the top flange weight distribution between the scaffolding and the self-supporting core. The new sequence has been widely used, both for highway and high speed railway bridges as it will be shown at the present paper.

This paper introduces a general description of viaduct construction with movable scaffolding system. It involves a short description of the scaffolding, its parts and operations as well as a description of the traditional sequence and the new sequence. At the description of the new sequence, its advantages and issues are described in order to show the different bridges that have been constructed in Spain until 2010. The description of the already constructed bridges is interesting because it shows the issues related to the new sequence and the way they have been faced in each bridge.

\section{Movable Scaffolding System (MSS): history, parts and operations}

Medium span bridges are constructed with three main procedures: precast beam bridges (Podolny \& Muller, 1982), (Xanthakos, 1994), (Manterola 2006), incremental launching method (Manterola, 2006), (Podolny \& Muller, 1982), (Viartola, 2004), (Rosignoli, 2002), (Pérez Fadón, 2004) and, finally, with movable scaffolding system.

The constructive process of viaducts by employing movable scaffolding system (MSS) is the most sophisticated (Daebritz, 2011) and from an environmental point of view it allows to separate the construction of the deck from the ground conditions. It can be enhanced by the improvement of the mobile equipments (Povoas, 2006) or by an organic longitudinal prestressing of the scaffolding itself (Pacheco P. et al 2008), (Pacheco P. et al, 2010). The organic prestressing consists in an active control system to reduce deformations and stresses by 
an external prestressing. The organic prestressing permits longer spans, monitoring the deck deformations and a more efficient use of the energy because the steel amount for organic prestressed scaffoldings is lower than the conventional MSS.

The movable scaffolding system (MSS) has been used since the sixties. The first time this construction system was used was in Germany: the Krahnember Viaduct, designed by Hans Wittfoht was built in 1961 (Leonhardt F., 1994). It was mainly from the seventies that its use has spread. Some of the most notable bridges at this time were those for Glattfelden Lättenbrücke viaducts, Telent Chavornay Ponts sur le Viaduc du Lac and the Swiss Gruyere. Investment level in movable scaffolding system (MSS) is such that their use is only justified, in the following cases (Manterola, 2006), (Tamayo \& Quell, 2009):

1) Viaducts with a number of spans equal to or greater than 5.

2) When the height above the ground is important and the use of conventional falseworks is not technically or economically advisable.

3) When it should overcome significant topography, such as deep valleys or wide rivers.

4) When the allowable loads on the ground are so small that loads during construction should focus on piles.

5) When environmental requirements imply that the ground should be little affected.

Span lengths reached in Spain are in the order of 70 meters, although more common span lengths are between 40-60 meters. Nevertheless, longer span length is being reached with organic prestressing (Pacheco et al, 2011). The execution time is about 2 weeks per span but it can be done in a week with a third shift that increases costs. During the calculations, the concentrated load introduced by the weight of the scaffolding at the front of the deck must be considered. The concentrated load disappears when the scaffolding moves to the next span. This hanging force depends on the weight of the scaffolding itself and the weight of the concrete of the span that is being constructed.

Then a more detailed description of the construction process will be carried out (Tamayo \& Quell, 2009), (SEOPAN, 2007), (FIB Bulletin 48), (ACHE, 2005). 
The movable scaffolding system can be of three different types, depending on the placement of the longitudinal girders:

1) Scaffolding under the bridge deck (figure 1).

2) Scaffolding on the bridge deck (figure 2).

3) Scaffolding halfway up: placed under the wings and near them.

The MSS elements are (figure 3):

- Formwork elements such as the panels, the stiffening trusses and the beams that support the formwork. It includes the elements that allow the descent and abatement of the formworks. The abatement can be done by hydraulic jacks.

- Longitudinal girders: longitudinal members that advance from one span to the next and transmit the loads to the supports.

- Crossbars: focus the load on the longitudinal girders and place most of the elements that regulate the slopes camber.

- Corbels: transmit loads to the piles. The MSS moves on the cantilevers, which also are capable of regulating and balancing. This system should permit the raising and lowering of the scaffolding and the outer formwork, and the transverse translation of the two half-scaffoldings.

- Hangers: they are the elements that transmit the load of the MSS to the executed span of the viaduct.

The launching operations are the next ones:

1) Removing the hangers on the deck if the scaffolding is under the deck.

2) Removing the formwork of the last executed span and opening the formwork or the scaffolding, to allow saving the piles for the next longitudinal displacement of the MSS.

3) Displacement to the next span, the longitudinal girders are hanging from the end of the last span that has been executed in such a way that the actual length of the span is reduced and vertical offset between two adjacent sections is avoided.

4) Closing the formwork or scaffolding and location in the final position.

5) Fixing the link to the deck if the scaffolding is under the deck. 
6) In the case of curved bridges, the deck must be inscribed within the scaffolding girders and the deck must be divided in segments that define the required shape.

The launching process between phases consists in the following steps:

1) Unlocking the hanger system from the back hanger (in case of scaffolding under the deck) and removing the scaffolding.

2) Transverse unlocking of the formwork and opening the scaffolding.

3) Ripping the longitudinal girders (in case of scaffolding under the deck).

4) Descent of the longitudinal girders.

5) Launching the scaffolding to place it at the final position.

6) Ripping girders (if it is scaffolding under the deck).

7) Final approach.

8) Transversal union of the formwork.

9) Hanging the MSS from the last span cantilever.

From the point of view of modern requirements of Health and Safety at work (Council, 1989), (Council, 1992), movable scaffolding system is a manufactured and industrial auxiliary structure so it allows the use of collective security measures. Operational risks are lower than with other constructive methods. The scaffolding requires a specific project in which basis for calculation of the scaffolding and the loads and combinations that have been considered should be detailed (Kwak \& Son, 2006). Manufacturing aspects of scaffolding, reception, control and mounting in work, the safety and health plan, operational handbooks, recommendations and organizational aspects are also required (Ministerio de Fomento, 2007).

In recent years, the procedure of construction with movable scaffolding system (MSS) has undergone some improvements and advances in order to achieve an organic prestress of scaffolding. The organic prestress permits saving material and reducing stresses in the structure (Pacheco et al, 2008). It also implies a significant advance in terms of environmental and sustainability requirements in the use of the resources. The organic prestress is able to be combined with the new sequence that is shown at this paper as the organic prestress is related to the scaffolding itself but the new sequence is related to the concrete deck construction. 
140 It has been noticed that the possible evolution of the traditional procedure of viaduct

141 construction with movable scaffolding system (MSS) goes in the direction of building partial 142 self-supporting cores to advance the formwork and complete then the cross section with simpler 143 and outside critical path aids.

\section{Movable scaffolding system: traditional sequence}

145 In order to highlight the differences between the traditional process and the new transverse 146 construction process, a description of the traditional method is carried out. Some disadvantages 147 of this traditional sequence are described.

148 The usual span length that has been achieved by the MSS method is in the range of 40-60 m.

149 The traditional sequence consists in the execution of the bottom flange and webs of the cross section in a first casting phase (Fig. 4a), subsequently executing the top flange (Fig. 4b). Then, once the necessary concrete strength for prestressing is achieved, the tendons are stressed and

152 the falsework advances to the next span. This sequence generally requires two weeks per span, although this period can be reduced by reducing curing times and carrying out the reinforcement and splicing activities at night. The casting joint between spans is placed at a distance equal to $0.2 \mathrm{~L}$ from the piles, where $\mathrm{L}$ is the length of each span, so that the bending moments at the joint between longitudinal phases are as low as possible.

157 The traditional method has the disadvantage that it primarily takes two weeks per span to be performed. If a reduction to one week is desired in execution time, it will involve a lot of critical path activities and increased costs because of the night shifts.

The use of the traditional sequence for two weeks per span does not involve any night activity or weekend activities, so a third shift is not necessary. This procedure does not have advantages in terms of execution time and the first casting phase should be done in the second week. On the other hand, if one week per span is considered, all activities are critical.

164 The traditional sequence for one span per week (Figure 5) consists of several phases. If the first span is considered, the phases are: 
1) $t=0$ days: the scaffolding supports the weight of the formworks and fresh concrete of the first casting phase.

2) $t=2$ days: The concrete of the first casting phase has hardened and the fresh concrete of independent of other activities.

\section{Movable scaffolding system: new sequence}

The first study of the new sequence was carried out by the Construction Engineering

2) It also requires the provision of an additional night shift for the activities related to placing the reinforcement and prestressing.

Reducing delays when placing the reinforcement is necessary if this solution is considered. Reinforcements should be previously pre-assembled and fitted, so that this activity can be

Department of the Polytechnic University of Catalonia (UPC), Spain, for Mecanotubo S.A. in 2004 (Aparicio \& Ramos, 2004) and comes from and original idea of Professor Aparicio from 
UPC. The new sequence (Figure 6a) consists in a first casting phase formed by the bottom

194 flange, webs and wings of the top flange. Once these items have reached the required strength, a partial stressing is carried out (50-75\% of the total force). The partial prestressing force allows a self-supporting core so that the MSS can advance to the next span without having executed the central area of the top flange. This procedure can be executed outside the critical path and with simple auxiliary means (Díaz de Terán, 2013).

This solution goes towards self-supporting cores that allow the movement of the scaffolding because they permit to complete the sectional scheme outside critical path and with more simple means (Aparicio \& Ramos, 2004), (Mozos et al, 2008), (Turmo et al, 2008).

If the procedure that takes two weeks per span is considered the new sequence it may be the easiest solution, without having activities in critical path that may delay the other activities. Indeed, night or weekend activities are not required because a third shift is not necessary. Reinforcement activities can be expedited by pre-assembling the reinforcement and placing it in just two days. Given the margins the execution time can be reduced to a week. The new sequence presents several phases (Figure 7):

1) $t=0$ days: the scaffolding supports the weight of the formworks and fresh concrete of the first casting phase.

2) $t=2$ days: the concrete of the first casting phase has hardened and the first prestressing force $(50-75 \%)$ is introduced.

3) t=3 days: as soon as the first casting phase is a self-supporting core, the scaffolding can move to the next span.

4) $t=4$ days: the concrete of the central part of the top flange is placed. It is supported by the self-supporting core with a prestressing force of $50-75 \%$.

5) $t=5$ days: since the concrete of the central zone of the top flange has hardened so the rest of the prestressing force (50-25\%) is introduced.

6) $t=7$ days: the scaffolding hangs from the front of the deck. The scaffolding transmits a part of its own weight and a part of the fresh concrete weight of the first casting phase of the next span. 
221 It should be noticed that at $\mathrm{t}=2$ days, the deck section is not completed, the prestressing force is

222 only $50-75 \%$ of the total force and the self-supporting core resists its weight. Sequence has been

223 considered for the first span. If other spans are considered the time equivalence is given at table

2242.

225 The construction process in a week, as it has been done to date (Figure 7), presents some

226 characteristics. Most of the activities related to the second casting phase are out of the critical

227 path and only a night shift in a weekend is needed to stress the resistant core. The concrete must reach the prestressing strength $36-48$ hours after being placed and a rapid hardening concrete is needed.

In general, the new sequence has the following advantages:

1) Improves performance and construction time.

2) The second casting phase of the section is outside the critical path.

3) The use of more simple auxiliary means is possible for the execution of this second casting phase.

4) Avoids problems of visual quality at the union of webs and wings.

5) The ducts are wrapped in the concrete from the beginning, unlike in the traditional system which leaves exposed the ducts between the web and the top flange until the second casting phase is executed.

6) This new procedure clarifies the distribution of loads between the MSS and the deck. The scaffolding should only support the weight of the first casting phase, while the weight of the second casting phase is supported by the self-supporting core.

7) It can imply an increase in capacity of existing MSS because the scaffolding does not have to support the weight of the entire section, but only the first casting phase.

However, in most of the viaducts that have been executed in Spain to date (González \& Alcala, 2008), (Viartola \& Pascual, 2005), (Crespo et al, 2008), there have been issues or disadvantages associated with this solution. These issues can be classified into (Díaz de Terán, 2013): 
1) Need to control the transverse bending of the self-supporting core that may require to place stiffening elements (small diaphragms or top bars) to avoid the deformability of the section.

2) Need two stages of prestressing. The first stage is needed to generate the self-supporting

\section{Viaducts that have been constructed with the new sequence}

\subsection{Road viaducts}

260

261

262

263

Road viaducts have a deck height/span length ratio of 1/20. From 2005 to 2009, the new sequence has been implemented in 6 road viaducts in Spain. These viaducts are as follows (Table 3):

- Magallan Viaduct (2005-2006), Mudejar Highway (A-23), between Zaragoza and Sagunto.

- Moutas Viaduct(2006-2007), A-63 Highway, Grado Ring Road.

- Viaducto de la presa de Lechago Dam Viaduct (2006-2007), Highway Levante-France, between Tramolamocha and Romans.

- Urumea Viaduct (2008), San Sebastian Second Ring Road.

- Llobregat Viaduct (2008), B 40 Highway.

- Cocentaina Viaduct(2009), Mediterranean Highway, between Alcoy and Cocentaina. 
271 In general, these viaducts have spans between 49 and $60 \mathrm{~m}$, with active reinforcement ranging

272 between 20 and $28 \mathrm{~kg} / \mathrm{m}^{2}$. Active reinforcement depends on the length of the span and the

273 height of the deck, which varies in these viaducts, between 2.5 and 3 meters. Concrete strength

274 used in road viaducts ranges from 25 to $40 \mathrm{MPa}$

275

\subsection{Railway viaducts}

276 On the other hand, railway viaducts with new evolutionary section have a deck height/span

277 length ratio of $1 / 15$. The viaducts of high-speed railway have been constructed with concrete

278 strength between 40 and $50 \mathrm{MPa}$.

279 The height of the deck ranges from 2.6 to $4 \mathrm{~m}$. Active reinforcement ranges from 24 to 32

$280 \mathrm{~kg} / \mathrm{m}^{2}$. The viaducts included in this group are as follows (Table 3):

281

282

283

- Requena Viaduct (2007), AVE Levante, between Caudete and Requena.

- Arroyo de la Vega Viaduct (2008), AVE Levante, between Cuenca and Olalla.

- Jucar Viaduct (2008), AVE Levante, between Cuenca and Olalla.

- Arroyo de Gauten Viaduct (2008), AVE Madrid- Levante, between Torrejon de Velasco and Sesena.

- Valdoriolf, BP and Cristofol Can Viaducts (2009), AVE Madrid- Barcelona-France.

- Ricardell Viaduct (2005), AVE Madrid-Barcelona-France.

- Gou Viaduct (2005), AVE Madrid-Barcelona-France.

- Llobregat Viaduct (2006-2007), AVE Madrid-Barcelona-France.

- Muga Viaduct (2006-2007), AVE Madrid-Barcelona- Viaduct.

- Fluvia Viaduct (2009), AVE Madrid-Barcelona- Viaduct.

- Francolí Viaduct (2009), Mediterranean Corridor.

293

\section{Facing the special issues related to the new constructive sequence}


There are three special issues related to the new solution that have not been treated in a uniform way to date. Instead, each designer has adopted a different solution taking into account their own experience in project designing.

297

\subsection{Issues arising from transverse bending}

298

The self-supporting core presents the issue related to transversal deflections of the deck because the section is not completed. These deflections can occur due to the weight of the core and to the partial $(50-75 \%)$ prestressing force therein.

Some designers have considered the necessity of placing stiffening elements that compensate the absence of the central section of the top flange. On the other hand, other designers have not considered stiffening elements because they suppose that the effect of the partial prestressing is enough to offset the transverse self-weight bending.

The stiffening elements that have been placed in former viaducts have been of three different types (Table 4): a ceiling slab at the front of the girder or above piles and steel bars on the girder:

1) Ceiling slab over the front of the girder: the solution that has been disposed at the Magallán Viaduct, Moutas Viaduct, Lechago Dam Viaduct, Urumea Viaduct, Llobregat Viaduct (highway B 40) and the Fluvia Viaduct.

2) Ceiling slab over piles: it is the solution that has resulted in the Urumea Viaduct (in combination with the above solution), Valdoriolf, Can Cristofol and BP viaducts.

3) Steel bars: they have been disposed in several viaducts, in combination with slab at the front of the phase, specifically in the Magallán Viaduct (bars every 8 meters), Llobregat Viaduct (bars every 14 meters) and the Fluvia Viaduct.

\subsection{Issues related to the removal of the internal formwork}

Removal of the inner formwork can be significantly hampered by the long length reinforcement splices between the two casting phases as they are prescribed by the codes (ACI, 2005), (CEBFIP, 1993), (Comision Permanente del Hormigon, 2008), (European Committee for 

viaducts it has been proceeded to place long length and straight splices, in other cases, it was decided to shorten this length by a $\mathrm{L}$ shape splice or it was decided to place a loop joint. The loop joint has the advantage of not requiring significant overlapping lengths between the first and the second casting phases (Díaz de Terán et al, 2013.1), (Díaz de Terán et al, 2013.2), (Contreras, 2012). The solutions that have been adopted are:

(Díaz de Terán et al, 2013.1), (Díaz de Terán et al, 2013.2).

\subsection{Issues concerning the percentage of prestressing force at the self-supporting core}

344 The new evolutionary solution has the disadvantage of requiring two tensioning or stressing stages for each span (Figure 7). The first stage corresponds to the introduction of the partial 
347 the deck is completed. This issue has not been treated in a systematic way at the analysed 348 viaducts.

349 The tensioning percentage in the first stage varies significantly between $33 \%$ and $75 \%$ of the total force (Table 4) and it is performed by fully tensioning a percentage of tendons equal to the percentage of prestressing force that should be provided.

\section{Conclusions}

Among the advantages of the new sequence over the traditional sequence, the most remarkable are related to clarifying the distributions of loads of the top flange between the scaffolding and the deck and improving the execution process by reducing the activities of the second casting phase in critical path. The first advantage involves an increased capacity of the current scaffoldings and the second one permits a construction process of one span per week without risk of delay.

On the other hand, the new sequence presents some issues related to the extraction of the inner formworks, transverse bending and need of two prestressing stages. Nevertheless, these issues have not been considered as a disadvantage enough to avoid the new sequence. Moreover, the new sequence is suitable good enough to replace the traditional sequence in many cases.

Furthermore, some of these issues have already been studied (Díaz de Terán, 2013) (Díaz de Terán et al, 2013.1), (Díaz de Terán et, 2013.2) or are under study and solutions have been found for them.

\section{Acknowledgment}

367 The study presented in this paper is part of the doctoral research of the first author of the paper, co-advised by the third and the fourth authors. It was done as a coordinated project between the Technical University of Catalonia (UPC) and the University of Castilla - La Mancha (UCLM),

370 funded by the Spanish Ministry of Science and Innovation. The global project (BIA2006-15471-

371 C02-01) has been directed by Prof. Gonzalo Ramos (UPC), from an original idea of Prof. Angel Aparicio (UPC). This research was part of the sub-project BIA2006-15471-C02-02, directed by 
Prof. José Turmo. The funding from the Spanish Ministry of Innovation and Science through the cited projects is greatly appreciated. As well as the funding from the Ministry of Science and Innovation of the Government of Castilla - La Mancha through projects BIA2009-13056 and PII2I09-0129-4085.

Our sincere and heartfelt thanks to Roberto Soto, Borja Beneitez and Albert Mas from Mecanotubo S.A. for their help and support that made this paper possible. The first authors would also want to thank to the whole Departament of Structures of the School of Engineering of Sao Carlos of the University de Sao Paulo (Brazil), for their help and support.

\section{Bibliography}

ACHE . Design and use of falseworks (in Spanish). Madrid: Colegio de Ingenieros de Caminos, Canales y Puertos. 2005.

ACI. ACI 318-05. Building Code Requirements for structural concrete. American Concrete Institute. 2005.

Aparicio, A., \& Ramos, G. Technical feasibility study of continuous span by span railway viaducts with evolutionary cross section construction (in Spanish). Barcelona: Technology Transfer Centre of the UPC for Mecanotubo SA. 2004.

CEB -FIP. Model Code 1990. London: Thomas Telford Ltd. 1993.

Comisión Permanente del Hormigón. EHE. Structural concrete standard(in Spanish). Ministerio de Fomento. 2008.

Contreras, C.P. Experimental verification of connections by loop joints and their application in evolutionary bridge construction (in Spanish). Barcelona. 2012.

Council. Council Directive 89/391/EEC of 12 June 1989 on the introduction of Measures to Encourage improvements in the safety and health of workers at work. Official Journal L183, 29/06/1989, 0001-0008. 
397

Council. Council Directive 92/57/EEC of 24 June on the Implementation of minimum safety and health requirements at temporary or mobile construction sites. Official Journal L245, 26/08/1992, 0006-0022.

Crespo, J., Glez . Cangas, J., \& Lorenzo, D. Moutas River Viaduct (in Spanish). IV Congress of the Scientific and Technical Association of Structural Concrete (ACHE). 2008.

Daebritz, M. Movable Scaffolding Systems. Structural Engineering International. V 21. Ed 4. Pp 413-418. 2011

Deutsches Institut für Normung. DIN 1045, Beton und Stahlbrton, Bemessung und Ausfürung. Berlin. 1988.

Díaz de Terán, J.R. New constructive procedure of viaducts with movable scaffolding system and new evolutive sequence (in Spanish). http://www.tdx.cat/handle/10803/129689. Barcelona. 2013.

Díaz de Terán, J.R., Turmo, J., Jorquera, J., Barragan, B., Ramos, G., \& Aparicio, A. Optimization of in situ construction of concrete decks: Flexure tests of compact splices of reinforcement between phases. Construction and Building Materials, 2013.1. V41, 191-203.

Díaz de Terán, J.R., Turmo, J., Jorquera, J., Barragan, B., Ramos, G., \& Aparicio, A. Shear -off strength of compact reinforcement for improved splicing site construction of concrete structures. Construction and Building Materials, 2013.2, 199-207.

European Committe for Standardization. UNE -ENV 1992-1-1. Eurocode 2. Design of concrete structures. Part 1-1. General rules and rules for buildings. Brussels. 2004.

FIB. Formwork and Falsework for Heavy Construction. FIB Bulletin 48. (S.F).

Gonzalez, F., \& Alcalá, J. Viaduct over the Magallán ravine on the A - 23 spressway Sagunto Somport (in Spanish). IV Congress of the Scientific and Technical Association of Structural Concrete. 2008. 
421 Kim, J. Williamson, E.B. Finite Element Modeling of Twin Steel Box Girder Bridges for

422 Redundancy Evaluation. Journal of Bridge Engineering. Online Publication Date: 13 Oct 2014.

423 Kwak, H., \& Son, J. Determination of design moments in bridges constructed with a movable 424 scaffolding system (MSS). Computers and Structures, 2006. 84, 2141-2150.

Manterola, J. Bridges. Notes for design, calculation and construction (in Spanish). Madrid:

Ministerio de Fomento Service Note 3/07 on instructions for use of falsework (mobile) in the construction of road bridges (in Spanish). Madrid. 2007.

Mozos, C., Caballero, A., Serrano, J., \& Prieto, S. Optimization analysis of construction process of large concrete viaducts with medium spans (in Spanish). IV Congress of the Scientific Technical Structural Concrete Association (ACHE). 2008.

Pacheco, P., Fonseca, A. A. , \& Coelho, H. The evolution of autocimbras. New needs and new solutions (in Spanish). IV Congress of the Scientific Technical Structural Concrete Association (ACHE). 2008.

Pacheco, P., Andre, A., Oliveira, T., et ál. Automation robustness of scaffolding systems strengthened with organic prestressing. Automation in Construction, 2010, V 19. 1-10 (ACHE). 2005. 
447 Povoas, A. A modern Concept of Movable Scaffolding System. Advances in Bridge 448 Maintenance, Safety Management and Life Cycle Performance. Proceedings of the Third 449 International Conference on Bridge Maintenance, Safety and Management. Porto. 2006.

Rosignoli, M. Bridge Launching. London: Thomas Telford Publishing. 2002.

451

452

SEOPAN Comisión Tecnológica. Handbook of design and use of movable scaffolding systems (in Spanish). Confederación Nacional de la Construcción. 2007.

Tamayo, P. G., \& Quell , E. B. Auxiliary temporary work structures. Enllaç, Butlletí INFORMATIU COLE • LEGI D' ENGINYERS TÈCNICS D' CATALAN Public Works, 2009. $20-22$

Turmo, J., Ramos, G., Serrano, J., Mozos, C., Aparicio, A., Prieto, S., et al. Structural implications of the reduction of the critical path in the construction of concrete viaducts with medium spans (in Spanish): tests. IV Congress of the Scientific Technical Structural Concrete Association (ACHE). 2008.

Viartola, L. Incrementally Launched Railway Bridges. Constructive aspects (in Spanish). Revista de Obras Públicas, 2004. 3445, 55-64.

Vicente, M.A. González, D.C. Fu, G. Static and Dynamic Testing of High-Speed Rail Bridges in Spain. Journal of Bridge Engineering. Online Publication Date: 13 Jun 2014

Voo, Y.L. Foster, S.J. Voo C.C. Ultrahigh-Performance Concrete Segmental Bridge Technology: Toward Sustainable Bridge Construction. Journal of Bridge Engineering. Online Publication Date: 3 Oct 2014

Xanthakos, P. P. Theory and design of bridges. New York: John Wiley \& Sons. 1994. 
Table 1. Equivalent days in different spans.

\begin{tabular}{|c|c|c|}
\hline \multicolumn{2}{|c|}{ Equivalent sequence days in different spans. Traditional sequence } \\
\hline span 1 & span 2 & span 5 \\
\hline $\mathrm{S}-0.3, \mathrm{~S}-0.4, \mathrm{~S}-1.1, \mathrm{~S}-1.2, \mathrm{~S}-1.3$ & $\mathrm{~S}-1.4, \mathrm{~S}-2.1, \mathrm{~S}-2.2, \mathrm{~S}-2.3$ & $\mathrm{~S}-4.3, \mathrm{~S}-4.4, \mathrm{~S}-5.1, \mathrm{~S}-5.2, \mathrm{~S}-5.3$ \\
\hline $\mathrm{t}=0$ days & $\mathrm{t}=7$ days & $\mathrm{t}=28$ days \\
\hline $\mathrm{t}=2$ days & $\mathrm{t}=9$ days & $\mathrm{t}=30$ days \\
\hline $\mathrm{t}=4$ days & $\mathrm{t}=11$ days & $\mathrm{t}=32$ days \\
\hline $\mathrm{t}=7$ days & $\mathrm{t}=14$ days & $\mathrm{t}=35$ days \\
\hline
\end{tabular}


Table 2. Equivalent days in different spans

\begin{tabular}{|c|c|c|}
\hline \multicolumn{3}{|c|}{ Equivalent sequence days in different spans. New sequence } \\
\hline span 1 & span 2 & span 5 \\
\hline S-0.3, S-0.4, S-1.1, S-1.2, S-1.3 & $\mathrm{S}-1.4, \mathrm{~S}-2.1, \mathrm{~S}-2.2, \mathrm{~S}-2.3$ & $\mathrm{~S}-4.3, \mathrm{~S}-4.4, \mathrm{~S}-5.1, \mathrm{~S}-5.2, \mathrm{~S}-5.3$ \\
\hline $\mathrm{t}=0$ days & $\mathrm{t}=7$ days & $\mathrm{t}=28$ days \\
\hline $\mathrm{t}=2$ days & $\mathrm{t}=9$ days & $\mathrm{t}=30$ days \\
\hline $\mathrm{t}=3$ days & $\mathrm{t}=10$ days & $\mathrm{t}=31$ days \\
\hline $\mathrm{t}=4$ days & $\mathrm{t}=11$ days & $\mathrm{t}=32$ days \\
\hline $\mathrm{t}=5$ days & $\mathrm{t}=12$ days & $\mathrm{t}=33$ days \\
\hline $\mathrm{t}=7$ days & $\mathrm{t}=14$ days & $\mathrm{t}=35$ days \\
\hline
\end{tabular}


Table 3. Chronological order of construction of viaducts built by the new sequence in Spain

\begin{tabular}{|c|c|c|c|c|c|c|c|c|c|c|c|}
\hline Emplacement of the viaduct & Year & Viaduct & Spans & $\begin{array}{r}\text { length } \\
\text { (m) } \\
\end{array}$ & $\begin{array}{c}\text { Width } \\
\text { (m) }\end{array}$ & $\begin{array}{l}\text { Height } \\
\text { (m) }\end{array}$ & $\begin{array}{c}\text { Concrete } \\
\text { strength } \\
\text { (Mpa) }\end{array}$ & $\begin{array}{c}\text { Long. } \\
\text { Pasive } \\
\text { Reinforce } \\
\text { (kg/m3) }\end{array}$ & \begin{tabular}{|c} 
Trans. \\
Pasive \\
Reinforce \\
$(\mathrm{kg} / \mathrm{m} 3)$
\end{tabular} & \begin{tabular}{|c} 
Active \\
Reinforce \\
$(\mathrm{kg} / \mathrm{m} 2)$
\end{tabular} & $\begin{array}{r}\text { \% Tendon } \\
\text { stressing } \\
\text { (1st phase }\end{array}$ \\
\hline AVE Madrid-Barcelona-Frontera Francesa & 2005 & Viaducto del Ricardell & 9 & 60 & 14.2 & 4 & 50 & 59 & 75 & 24.99 & 60 \\
\hline AVE Madrid-Barcelona-Frontera Francesa & 2005 & Viaducto del Gou & 5 & 50 & 14.2 & 4 & 50 & 59 & 75 & 24.99 & 60 \\
\hline Autovía Mudejar de Sagunto a Zaragoza A 23 & $2005-2006$ & Viaducto de Magallán & $2 \times 10$ & 49 & 13.3 & 2.85 & 25 & 39.7 & 121 & 22.21 & 67 \\
\hline Autovía A 63. Variante de Grado & $2006-2007$ & Viaducto del río Moutas & $2 \times 14$ & 55 & 11.9 & 2.7 & 35 & 44.5 & 74.3 & 24.07 & 75 \\
\hline $\begin{array}{l}\text { Autovía Levante a Francia. Tramolamocha- } \\
\text { Romanos }\end{array}$ & $2006-2007$ & $\begin{array}{l}\text { Viaducto del embalse de } \\
\text { Lechago }\end{array}$ & $2 \times 14$ & 50 & $1.75-11$ & 2.5 & 35 & 34 & 78 & 19.50 & 50 \\
\hline AVE Madrid-Barcelona-Frontera Francesa & $2006-2007$ & Viaducto del Llobregat & 11 & 60 & 14.2 & 4 & 50 & 62 & 82 & 31.33 & 60 \\
\hline AVE Madrid-Barcelona-Frontera Francesa & $2006-2007$ & Viaducto del Muga & 9 & 60 & 14.2 & 4 & & & & & \\
\hline AVE Levante. Tramo: Caudete-Requena & 2007 & Viaducto V1 & 20 & 43 & 14 & 3.02 & & & & & \\
\hline Segundo cinturón de San Sebastián & 2008 & Viaducto del Urumea & $20+19$ & 55 & 14 & 2.5 & 40 & & & & \\
\hline AVE Levante. Tramo: Cuenca-Olalla & 2008 & $\begin{array}{l}\text { Viaducto del arroyo de la } \\
\text { Vega }\end{array}$ & 15 & 33.5 & 14 & 2.6 & 50 & 53.3 & 90.7 & 24.12 & \\
\hline AVE Levante. Tramo: Cuenca-Olalla & 2008 & Viaducto del Júcar & 13 & 45 & 14 & 3.1 & 50 & 45 & 102 & 31.09 & 33 \\
\hline Autovía B 40 & 2008 & Viaducto del río Llobregat & $2 \times 12$ & 60 & 14.8 & 3 & 40 & 31 & 120 & 27.97 & \\
\hline $\begin{array}{l}\text { AVE Madrid-Levante. Tramo: Torrejón de } \\
\text { Velasco-Seseña }\end{array}$ & 2008 & $\begin{array}{l}\text { Viaducto sobre el arroyo } \\
\text { del Gautén }\end{array}$ & $10+11$ & 40 & 8.5 & 3 & & & & & \\
\hline AVE Madrid-Barcelona-Frontera Francesa & 2009 & $\begin{array}{l}\text { Viaductos de Valdoriolf, } \\
\text { BP y Can Cristofol }\end{array}$ & $19+6+5$ & 42 & 14 & 2.92 & 45 & 30 & 70 & 32.23 & 50 \\
\hline $\begin{array}{l}\text { Autovía del Mediterráneo. Tramo: Alcoy- } \\
\text { Cocentaina }\end{array}$ & 2009 & Viaductos E 12 y E 15 & $2 \times 4,2 \times 5$ & 53.5 & 12.3 & 2.5 & 35 & 31 & 83 & 25.66 & \\
\hline AVE Madrid-Barcelona-Frontera Francesa & 2009 & Viaducto del río Fluviá & 14 & 60 & 14 & 4 & 45 & 62 & 90 & 31.56 & 60 \\
\hline $\begin{array}{lll}\text { Conexión Ferroviaria Corredor del } \\
\text { Mediterráneo }\end{array}$ & 2009 & Viaducto del río Francolí & 13 & 50 & 13.6 & 3.5 & 50 & 69 & 135 & 30.34 & \\
\hline
\end{tabular}


Table 4. Different solutions to the issues related to the new sequence

\begin{tabular}{|c|c|c|c|c|c|c|c|c|c|c|c|}
\hline \multirow[b]{2}{*}{ Emplacement of the viaduct } & \multirow[b]{2}{*}{ Year } & \multirow[b]{2}{*}{ Viaduct } & \multirow{2}{*}{$\begin{array}{c}\% \text { of } \\
\text { tendon } \\
\text { stressing } \\
\text { (1st } \\
\text { phase) }\end{array}$} & \multicolumn{3}{|c|}{ transverse deflection control } & \multicolumn{5}{|c|}{ Splice at the jo int of the upper slab } \\
\hline & & & & $\begin{array}{c}\text { upper } \\
\text { slab over } \\
\text { span } \\
\text { front }(m)\end{array}$ & $\begin{array}{c}\text { upper } \\
\text { slab } \\
\text { over } \\
\text { piles (m) }\end{array}$ & teel bars & \begin{tabular}{|l} 
straight \\
upper bars
\end{tabular} & $\begin{array}{l}\text { straight } \\
\text { down bars }\end{array}$ & $\begin{array}{l}\text { "L" shaped } \\
\text { upper bars }\end{array}$ & $\begin{array}{l}\text { "L" shaped } \\
\text { down bars }\end{array}$ & Loop Joint \\
\hline AVE M adrid-Barcelona-Frontera Francesa & 2005 & \begin{tabular}{|l} 
Viaducto de \\
Ricardell
\end{tabular} & 60 & NO & NO & NO & NO & NO & NO & NO & $\begin{array}{l}\text { ب16. Overlapping } \\
67 \mathrm{~cm}\end{array}$ \\
\hline A VE M adrid-Barcelona-Frontera Francesa & 2005 & $\begin{array}{l}\text { Viaducto de } \\
\text { Gou }\end{array}$ & 60 & NO & NO & NO & NO & NO & NO & NO & $\begin{array}{l}\varphi 16 . \text { Overlapping } \\
67 \mathrm{~cm}\end{array}$ \\
\hline $\begin{array}{l}\text { Autovía Mudéjar de Sagunto a Zaragoza A } \\
23\end{array}$ & $2005-2006$ & \begin{tabular}{|ll} 
Viaducto & de \\
M agallán &
\end{tabular} & 67 & 2.5 & NO & $\begin{array}{c}\text { YES. } \\
\text { every } 8 \mathrm{~m}\end{array}$ & NO & NO & NO & NO & $\begin{array}{l}\text { 16. Overlapping } \\
40 \mathrm{~cm}\end{array}$ \\
\hline Auto vía A 63. Variante de Grado & $2006-2007$ & $\begin{array}{l}\text { Viaducto del río } \\
\text { Moutas }\end{array}$ & 75 & 2 & NO & NO & NO & NO & NO & NO & $\begin{array}{l}20 . \text { Overlapping } \\
20 \mathrm{~cm}\end{array}$ \\
\hline $\begin{array}{l}\text { Autovía Levante a Francia. Tramolamocha- } \\
\text { Romanos }\end{array}$ & $2006-2007$ & \begin{tabular}{|ll} 
Viaducto & del \\
embalse & de \\
Lechago & \\
\end{tabular} & 50 & 2.5 & NO & NO & \begin{tabular}{|l|}
$\varphi^{20}$ \\
Overlapping \\
$180 \mathrm{~cm}$ \\
\end{tabular} & $\begin{array}{l}\varphi^{20} \\
\text { Overlapping } \\
105 \mathrm{~cm}\end{array}$ & NO & NO & NO \\
\hline A VE M adrid-B arcelona-Frontera Francesa & $2006-2007$ & \begin{tabular}{|ll}
$\begin{array}{l}\text { Viaducto } \\
\text { Llobregat }\end{array}$ & de \\
\end{tabular} & 60 & NO & NO & NO & NO & NO & NO & NO & $\begin{array}{l}\varphi_{20 .} \text { Overlapping } \\
67 \mathrm{~cm}\end{array}$ \\
\hline AVE M adrid-Barcelona-Frontera Francesa & $2006-2007$ & $\begin{array}{l}\text { Viaducto de } \\
\text { M uga }\end{array}$ & & NO & NO & NO & NO & NO & NO & NO & 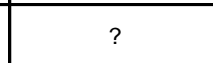 \\
\hline A VE Levante. Tramo: Caudete-Requena & 2007 & $\begin{array}{ll}\text { Viaducto de } \\
\text { Requena }\end{array}$ & & NO & NO & NO & $?$ & ? & ? & ? & ? \\
\hline Segundo Cinturón de San Sebastián & 2008 & $\begin{array}{l}\text { Viaducto del } \\
\text { Urumea }\end{array}$ & & 2 & 2 & NO & $?$ & $?$ & $?$ & ? & ? \\
\hline AVE Levante. Tramo: Cuenca-Olalla & 2008 & $\begin{array}{ll}\text { Viaducto } & \text { del } \\
\text { arroyo de la } \\
\text { Vega }\end{array}$ & & NO & NO & NO & NO & \begin{tabular}{|l}
$\varphi 16$. \\
Overlapping \\
$45 \mathrm{~cm}$
\end{tabular} & $\begin{array}{l}\varphi 16 . \\
\text { Overlapping } \\
55 \mathrm{~cm}\end{array}$ & NO & NO \\
\hline AVE Levante. Tramo: Cuenca-Olalla & 2008 & $\begin{array}{l}\text { Viaducto del } \\
\text { Júcar }\end{array}$ & 33 & NO & NO & NO & NO & NO & $\begin{array}{l}20 . \\
\text { Overlapping } \\
100 \mathrm{~cm} \\
\end{array}$ & $\begin{array}{l}\varphi 16 . \\
\text { Overlapping } \\
80 \mathrm{~cm} \\
\end{array}$ & NO \\
\hline \begin{tabular}{|l|l} 
Autovía B 40 \\
\end{tabular} & 2008 & \begin{tabular}{|l} 
Viaducto del río \\
Llobregat
\end{tabular} & & 2 & NO & \begin{tabular}{|c|} 
YES. \\
every $14 \mathrm{~m}$
\end{tabular} & \begin{tabular}{|l|}
$\varphi 20$. \\
Overlapping \\
$150 \mathrm{~cm}$ \\
\end{tabular} & ? & NO & NO & NO \\
\hline $\begin{array}{l}\text { AVE M adrid-Levante. Tramo: Torrejón de } \\
\text { Velasco-Seseña }\end{array}$ & 2008 & $\begin{array}{l}\text { Viaducto sobre } \\
\text { el arroyo de } \\
\text { Gautén }\end{array}$ & & ? & ? & ? & ? & ? & ? & ? & ? \\
\hline A VE M adrid-Barcelo na-Frontera Francesa & 2009 & $\begin{array}{l}\text { Viaductos de } \\
\text { Valdoriolf, BP y } \\
\text { Can Cristofol }\end{array}$ & 50 & NO & 2.5 & NO & NO & NO & NO & NO & $\begin{array}{l}\varphi 25 . \text { Overlapping } \\
65 \mathrm{~cm}\end{array}$ \\
\hline $\begin{array}{l}\text { Autovía del Mediterráneo. Tramo: Alcoy- } \\
\text { Cocentaina }\end{array}$ & 2009 & $\begin{array}{l}\text { Viaductos E } 12 \\
\text { yE } 15\end{array}$ & & ? & $?$ & $?$ & NO & NO & NO & NO & $\begin{array}{l}\text { 16. Overlapping } \\
40 \mathrm{~cm}\end{array}$ \\
\hline A VE M adrid-B arcelona-Fro ntera Francesa & 2009 & $\begin{array}{l}\text { Viaducto del río } \\
\text { Fluviá }\end{array}$ & 60 & 2 & NO & YES & NO & NO & $\begin{array}{l}\varphi^{20} \\
\text { Overlapping } \\
120 \mathrm{~cm}\end{array}$ & $\begin{array}{l}\varphi^{20 .} \\
\text { Overlapping } \\
120 \mathrm{~cm}\end{array}$ & NO \\
\hline $\begin{array}{|lll|}\text { Conexión Ferroviaria } & \text { Corredor del } \\
\text { Mediterráneo } & & \\
\end{array}$ & 2009 & $\begin{array}{l}\text { Viaducto del río } \\
\text { Francolí }\end{array}$ & & NO & NO & NO & NO & $\begin{array}{l}\varphi^{16 .} \\
\text { Overlapping } \\
100 \mathrm{~cm}\end{array}$ & $\begin{array}{l}\varphi 20 . \\
\text { Overlapping } \\
100 \mathrm{~cm}\end{array}$ & NO & NO \\
\hline
\end{tabular}


Click here to download Figure: Figure 1.pdf

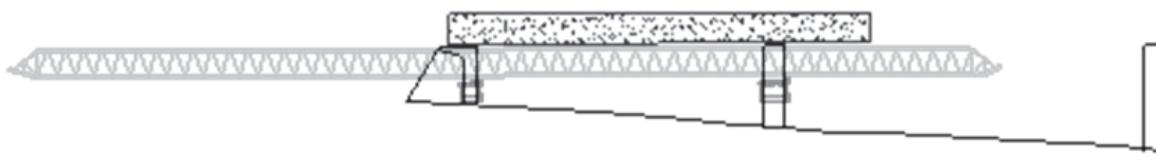

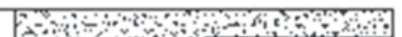

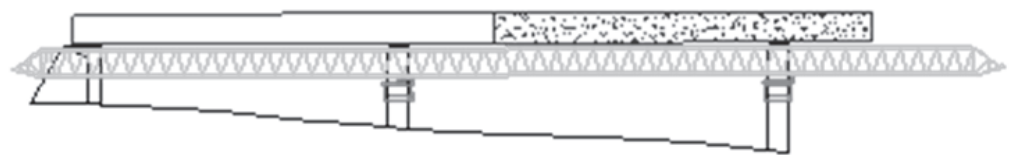

Figure 1 Advance scheme of the MSS. 


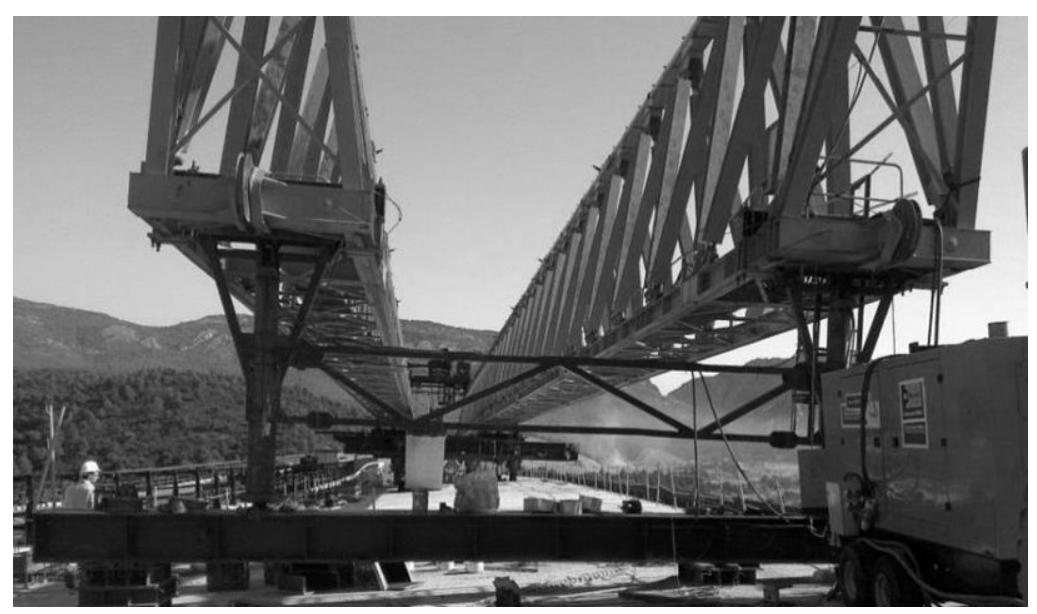

Figure 2. Movable Scaffolding System (MSS) on the bridge deck. 
Click here to download Figure: Figure 3.pdf

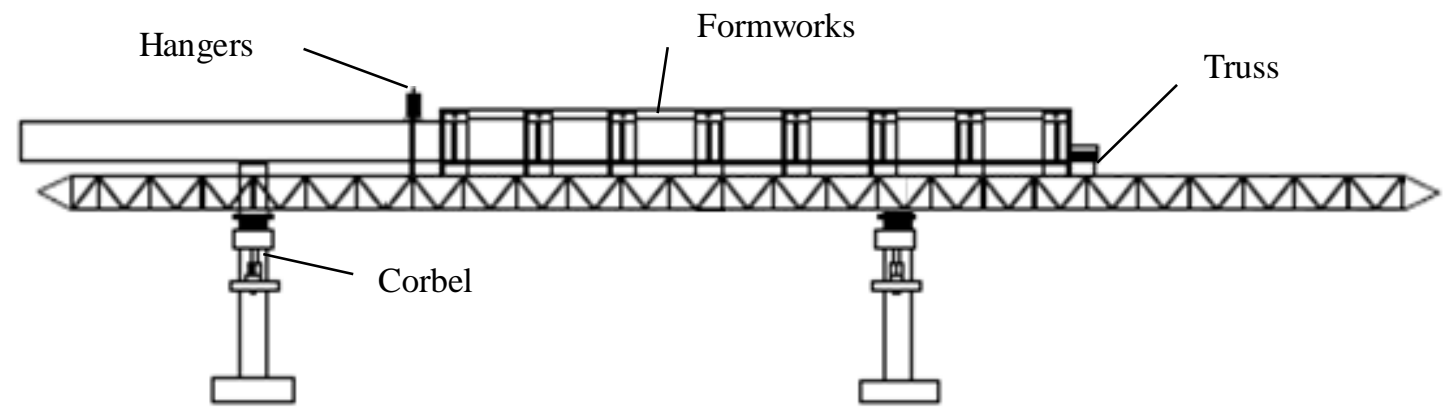

Figure 3. Different parts of the MSS. 


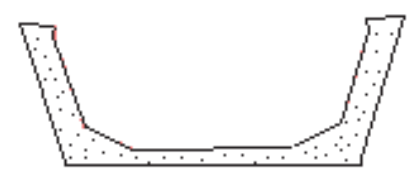

a

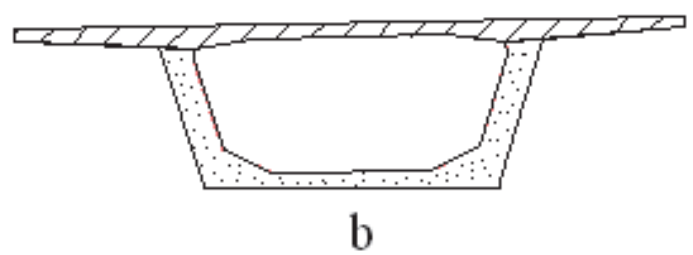

b

Figure 4. Traditional sequence. a) Phase 1. b) Phase 2. 

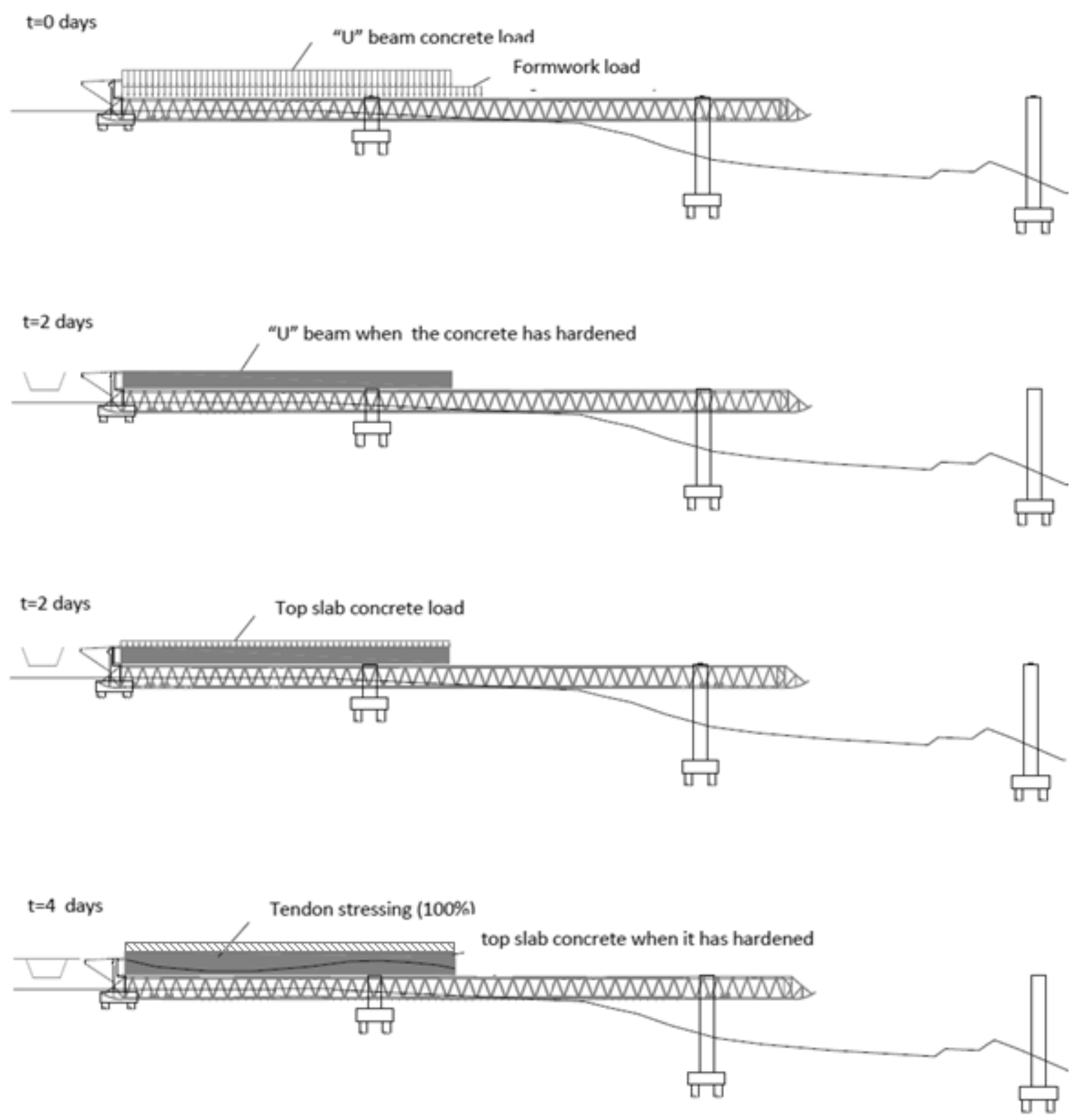

$t=4$ days

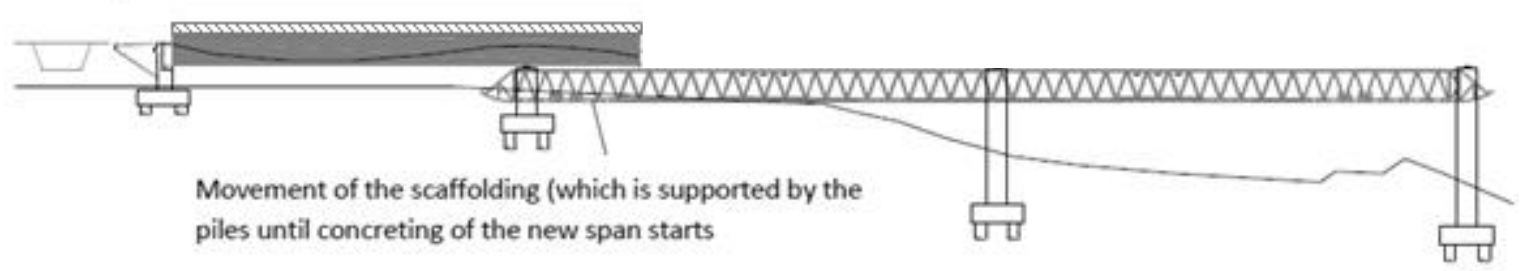




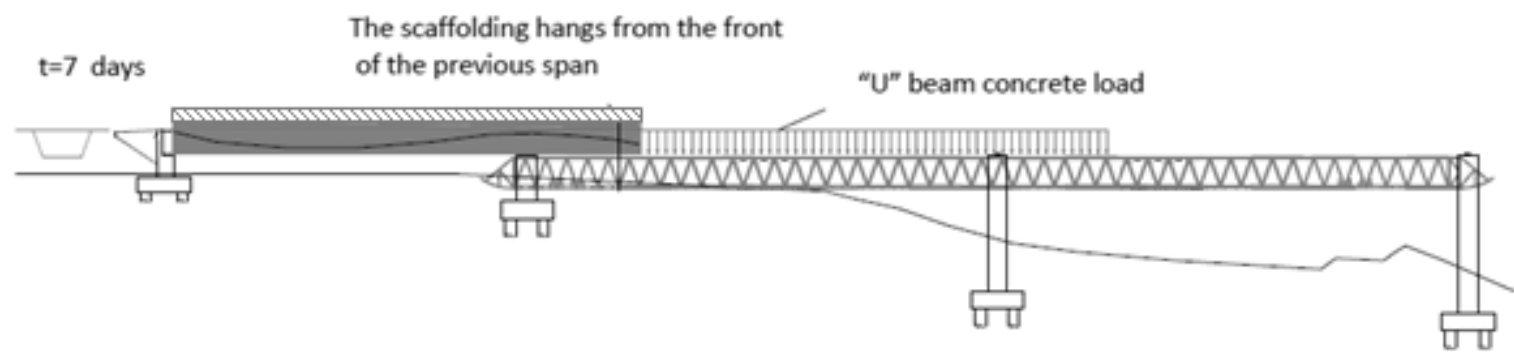

Figure 5. Traditional Construction Sequence. 

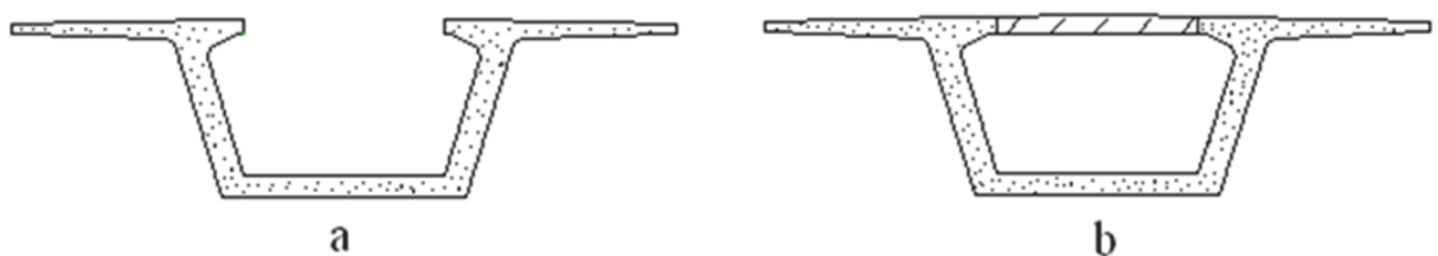

Figure 6. New sequence with MSS. a) Phase 1. b) Phase 2 

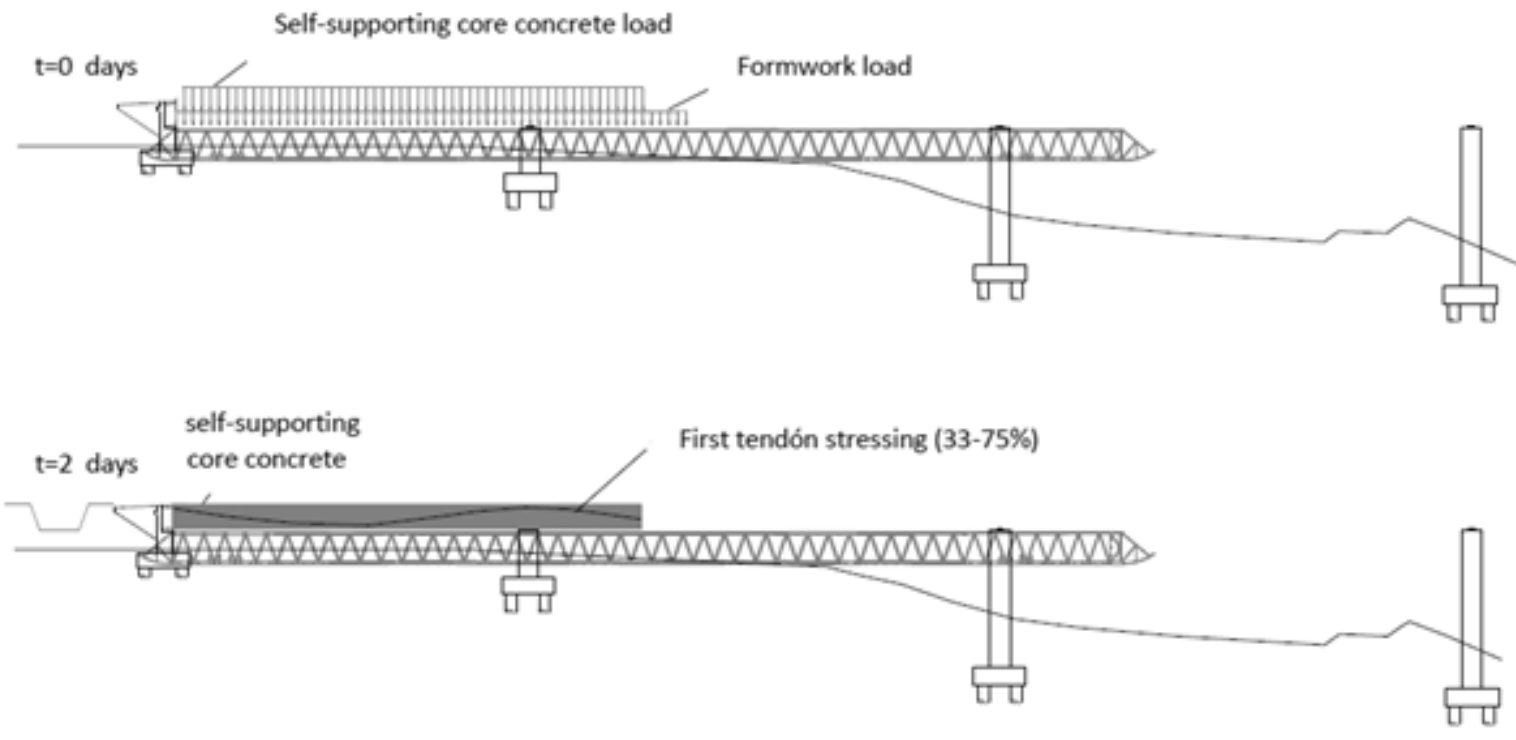

$\mathrm{t}=3$ days
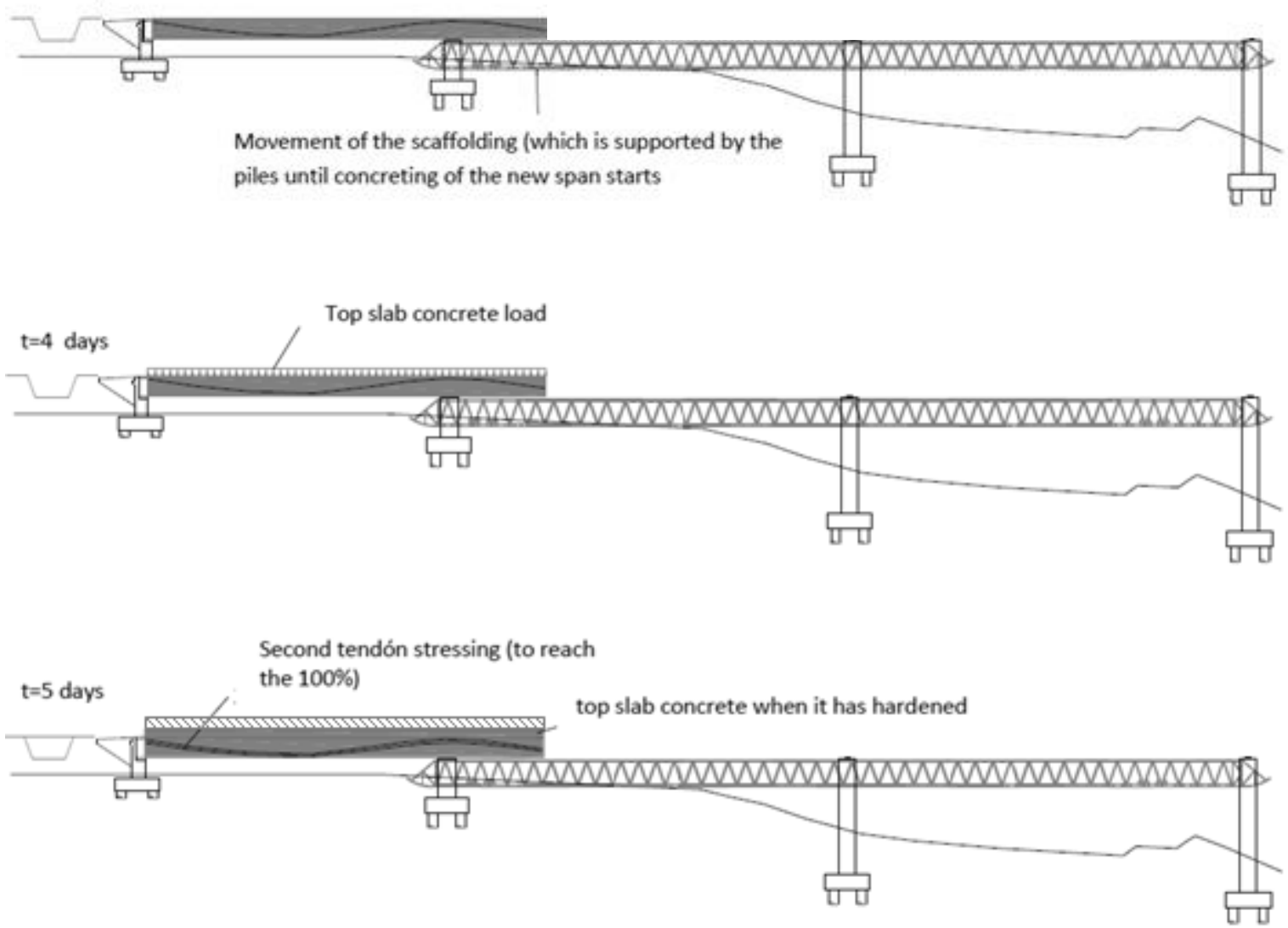


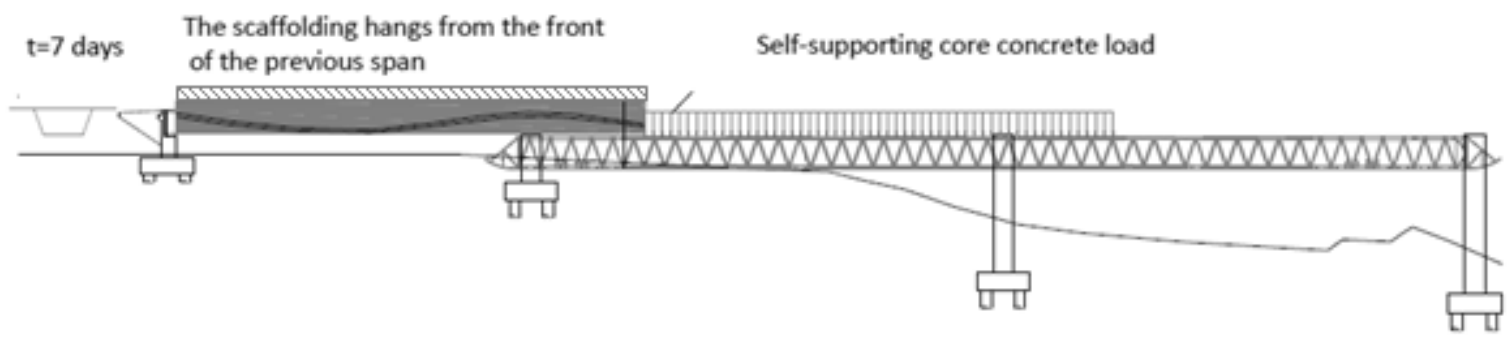

Figure 7. New Construction Sequence. 


\section{Figure}

Click here to download Figure: Figure 8.pdf

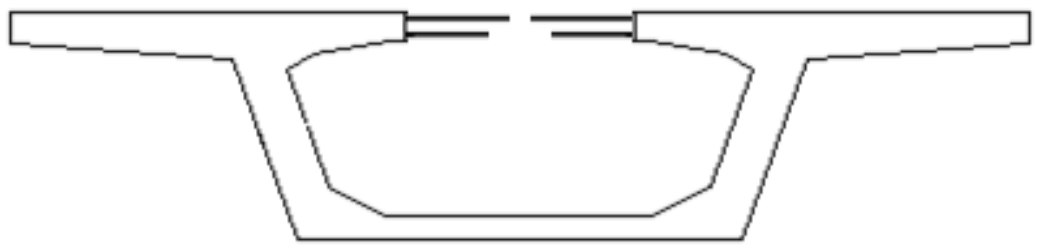

Figure 8. Straight reinforcement splicing by overlapping at the casting joint. 


\section{Figure}

Click here to download Figure: Figure 9.pdf

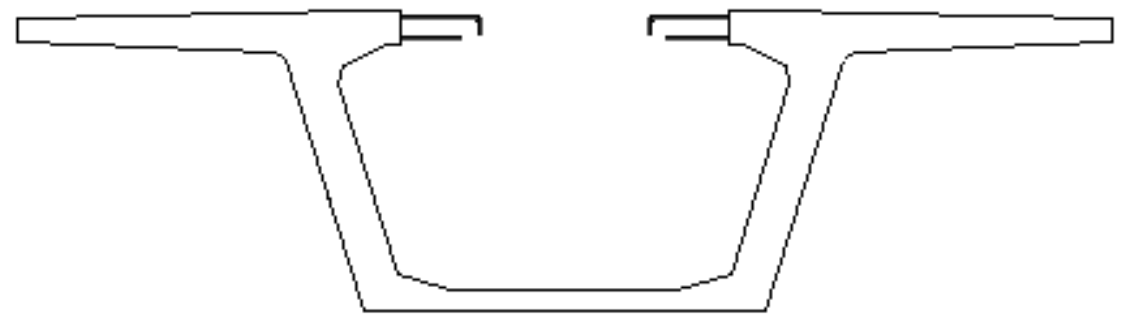

Figure 9. L reinforcement splicing by overlapping at the casting joint. 


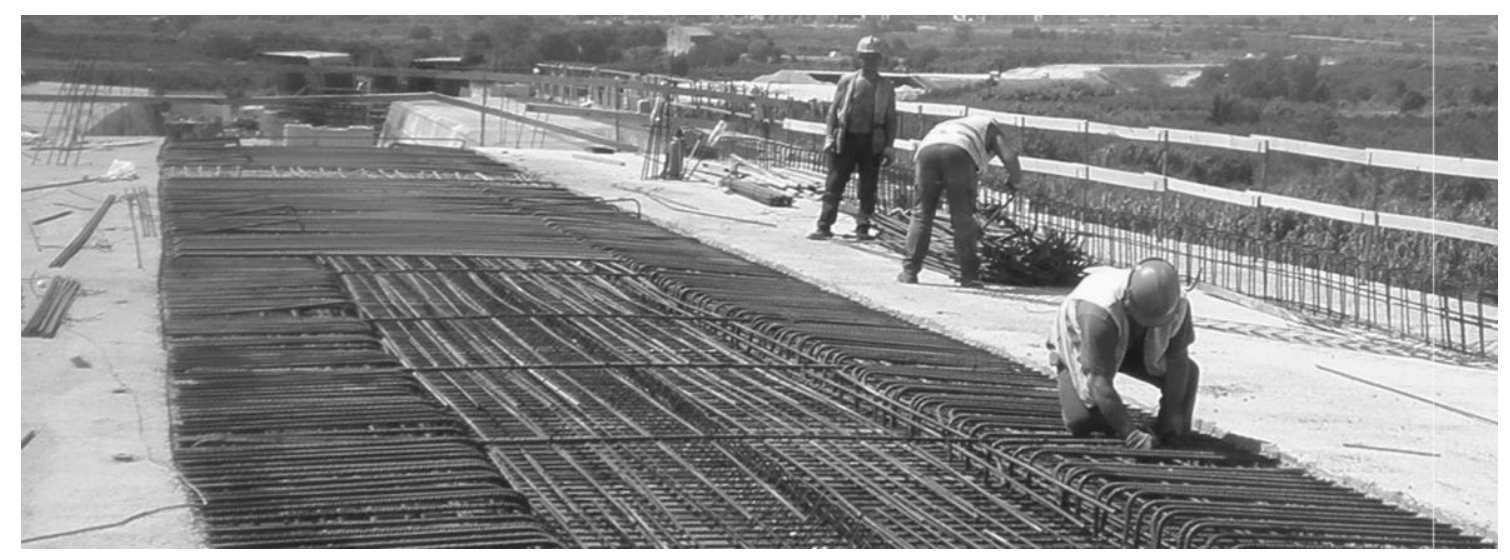

Figure 10. Overlapping loop joints. 


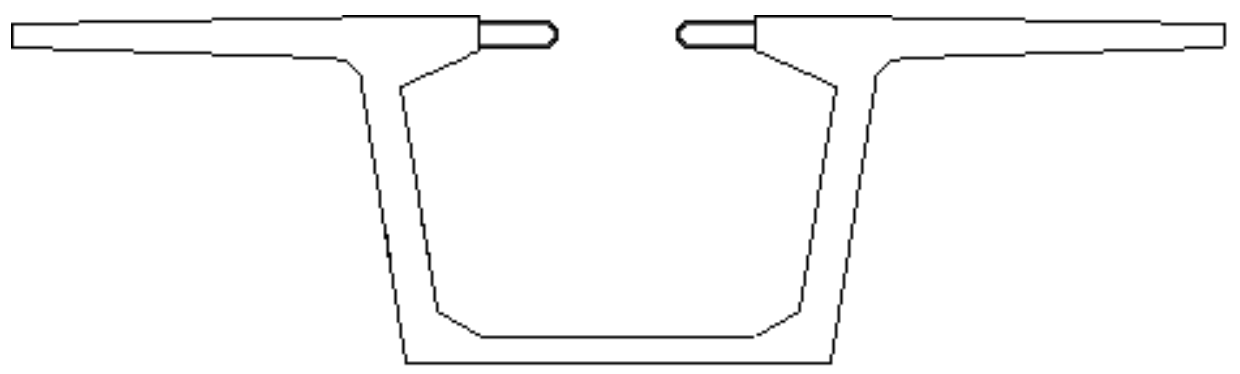

Figure 11. Overlapping loop joints. 

Click here to download Figure: Figure 12.pdf

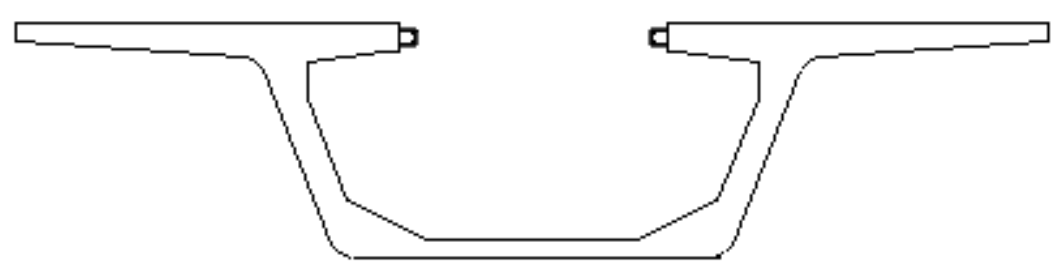

Figure 12. Loop joints: compact splices 


\section{LIST OF FIGURE CAPTATIONS}

Figure 1 Advance scheme of the MSS.

Figure 2. Movable Scaffolding System (MSS) on the bridge deck.

Figure 3. Different parts of the MSS.

Figure 4. Traditional sequence. a) Phase 1. b) Phase 2.

Figure 5. Traditional Construction Sequence.

Figure 6. New sequence with MSS. a) Phase 1. b) Phase 2.

Figure 7. New Construction Sequence.

Figure 8. Straight reinforcement splicing by overlapping at the casting joint.

Figure 9. L reinforcement splicing by overlapping at the casting joint.

Figure 10. Overlapping loop joints.

Figure 11. Overlapping loop joints.

Figure 12. Loop joints: compact splices.

\section{LIST OF TABLE CAPTATIONS}

Table 1. Equivalent days in different spans.

Table 2. Equivalent days in different spans.

Table 3. Chronological order of construction of viaducts built by the new sequence in Spain.

Table 4. Different solutions to the issues related to the new sequence. 